\title{
MIR17 Gene
}

National Cancer Institute

\section{Source}

National Cancer Institute. MIR17 Gene. NCI Thesaurus. Code C80715.

This gene is involved in the regulation of gene expression and plays an oncogenic role in hepatocellular, lung, colorectal, thyoid and breast carcinomas, various leukemias and lymphomas, and neuroblastoma.. 